\title{
Case Based Teaching of Microcomputer Principle and Application
}

\author{
Guangfeng Chen ${ }^{\mathrm{a},}{ }^{*}$, Linxia Wang ${ }^{\mathrm{b}}$, Xiangping Yang ${ }^{\mathrm{c}}$, Huimin $\mathrm{Li}^{\mathrm{d}}$, Yan $\mathrm{Li}^{\mathrm{e}}$ \\ College of Mechanical Engineering, Donghua University Shanghai, 201620, China \\ achengf@dhu.edu.cn, bsnowlxwang@163.com, cyangxp@dhu.edu.cn, dlihm12@dhu.edu.cn, \\ eliyanly@dhu.edu.cn
}

Keywords: Microcomputer principle, SCM; case teaching, curriculum reform.

\begin{abstract}
This paper explores case-based microcomputer principle teaching methods combined with case teaching. According to the teaching outline, divide the content of the curriculum into a number of knowledge points. Select typical SCM applications to design typical cases, merge knowledge points into cases, and write case notes. In the course of teaching, actively mobilizing the enthusiasm of students and taking the case as the main line of teaching methods. Compared with the traditional teaching methods, the case teaching method would stimulate students' interest in learning, and promote the cultivation of students' integrated application ability of single chip microcomputer.
\end{abstract}

\section{Introduction}

With SCM's advantages of high integration, strong processing capability, high reliability, simple system structure, it becomes a typical embedded system that has been successfully applied to industrial automation, home appliances, communications, military, etc. "Microcomputer Principle and Application" is a course with strong theoretical and practical, which is mainly to impart the application theory knowledge of SCM. It is a professional basic course for many majors, such as computers, machinery, electrical, communications, etc., and plays more and more important role in the training of students' professional skills[1].

\section{Problems in Microcomputer Principle and Application Teaching}

Students don't understand the development process of SCM application system. In the facing of actual circuit system design or new problems, the initiative and innovative obviously don't enough[2]. Not only did not grasp the principle of SCM and its basic content, but don't understand what the SCM development process, we can not achieve the established teaching objectives and teaching requirements. There are several reasons for the phenomenon.

\subsection{Unreasonable Teaching Main Line}

In traditional teaching process, teacher as the mainstay, students as a listener, and they follow the teachers passively. Because of the separation of theoretical teaching and practice, students generally reflect that the SCM is difficult to cross the threshold. On the other hand, most of the textbooks introduce the principle, internal modules and timing of SCM deeply. However, the lack of application of SCM in system design makes the textbooks are divorced from teaching activities.

\subsection{Disadvantages in the Experiment}

"Box experiment" limits students cognitive[3]. First, the experimental content is mainly a confirmatory experiment and is short of comprehensive design links. It is not conducive improve the programming ability. Second, it is difficult to achieve the desired results because of higher experimental equipment failure rate of the experiment.

\subsection{Unreasonable Arrangements in Teaching Practice Links}

In the context of the compression class, it results in few opportunities for students in teaching. Other practice courses involving SCM knowledge are arranged at other time periods, so that most of the students in later practice courses had forgotten the course knowledge and did not perform well.

\subsection{Unscientific Course Assessment Methods}

The examination of this course mainly adopts the way of the normal grade and the final grade. The emphasis is still on the examination of the theory, neglecting the examination of the application ability 
and not conforming to the characteristics of the course. Other teaching practice assessments are even useless. The phenomena is very prominent that some students copy other reports.

\section{Case Teaching'S Application in Microcomputer Principle}

The case teaching method has become the first choice in the teaching reform of microcomputer principle because of the transformation from teacher-centered to student-centered, textbook- centered to case-centered and classroom-centered to practice-centered.

Case teaching is create a real teaching environment for students to learn with real tasks. The essence is to induce, enhance and maintain the learners' achievement motivation of case teaching. Because it is not that center based on textbooks, it is necessary to design the corresponding case and equipped with specialized course ware lectures. The design of the case should be set around the basic knowledge of SCM, including the knowledge points of the course as far as possible. In this way, students can easily get started if they invest their energy, so that they can quickly master the practical skills of SCM, and at the same time, improve their practical ability and innovative ability.

\subsection{Basic Methods of Case Teaching}

Apply the "case teaching method" during the teaching process, the typical cases are carefully designed to make the case content conform to the knowledge module. The combination of "teaching and learning, teaching and training" makes learning and practice to promote themselves each other.

Case selection: Design cases need to integrate knowledge points and typical single chip applications in each chapter, so that knowledge points can be covered as much as possible.

Case lecture writing: Before the implementation of the "case" teaching, case materials should be fully prepared. For each case, the related information is developed in advance, including: case diagram, program debugged, simulation results, and write case training handouts.

Demonstration and evaluation of case implementation: When each group is finished, the case discussion time is arranged in the following courses. The implementation effect and innovation of the case are demonstrated, and the problems encountered in the production process are put forward. The teachers check the program of student development, observe the production effect, and comprehensively evaluate the results.

Expansion of the case: Based on case content, the case is further improved. When each project completed, the basic content of principle and application of Microcomputer in this course has been finished. According to all items carried out and the total number and quality of the corresponding practical programs developed by the students, the total score was assessed by the teacher and the total results were counted in proportion to the end of term.

\subsection{Typical Case Design}

Taking the timing/counting teaching as an example, a SCM controlled frequency meter is designed as an implementation case. The principle diagram and flowchart are shown respectively in Fig. 1 and Fig. 2. The content of this case implementation is divided as shown in Table 1.

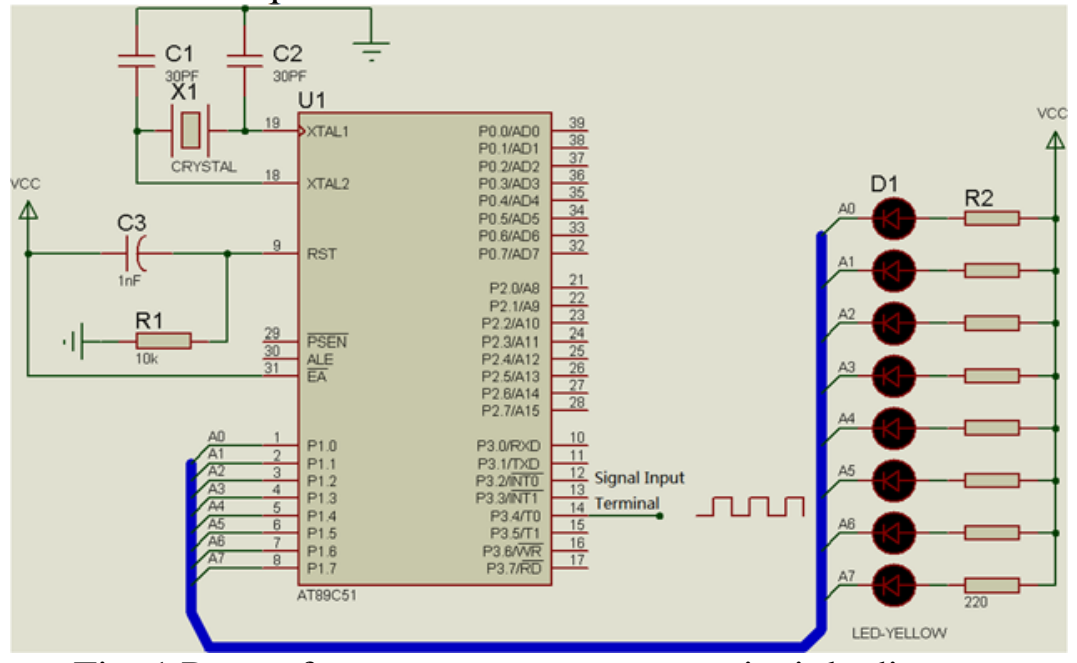

Fig. 1 Power frequency measurement principle diagram 


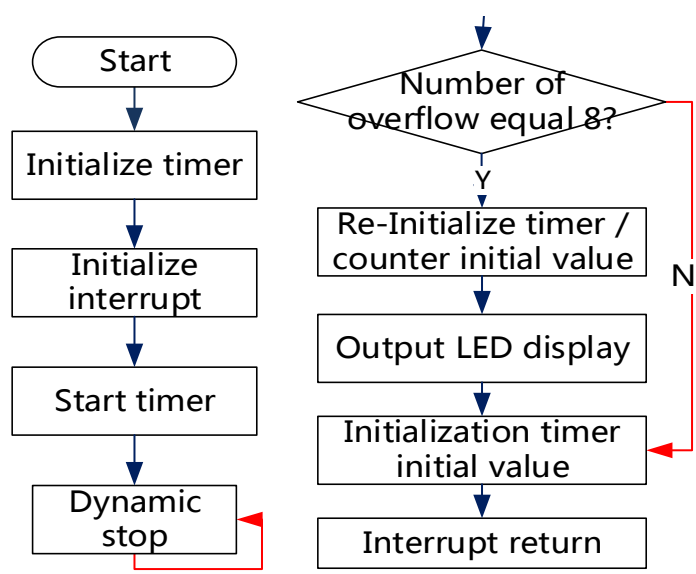

Fig. 2 Case flow chart

Table 1. Resolution of case content of frequency frequency meter

\begin{tabular}{|c|c|c|c|c|}
\hline sn & Task name & Guidance content & Knowledge point & Task target \\
\hline 1 & $\begin{array}{c}\text { Minimum } \\
\text { system of SCM }\end{array}$ & $\begin{array}{l}\text { Crystal oscillator } \\
\text { circuit; reset circuit }\end{array}$ & $\begin{array}{l}\text { Time sequence and reset of } \\
\text { SCM }\end{array}$ & $\begin{array}{c}\text { Mastering } \\
\text { composition of } \\
\text { minimum system }\end{array}$ \\
\hline 2 & $\begin{array}{l}\mathrm{I} / \mathrm{O} \text { port } \\
\text { controlled } \\
\text { LEDs } \\
\end{array}$ & $\begin{array}{l}\text { Use of I/O port, LED } \\
\text { driver circuit, related } \\
\text { instructions } \\
\end{array}$ & $\begin{array}{c}\text { I/O structure \& principle; } \\
\text { driving capability ; } \\
\text { instructions; emulators; }\end{array}$ & $\begin{array}{l}\text { Light emitting } \\
\text { diode control by } \\
\text { I/O control } \\
\end{array}$ \\
\hline 3 & $\begin{array}{l}\text { External pulse } \\
\text { counting }\end{array}$ & $\begin{array}{l}\text { The principle of } \\
\text { software and hardware } \\
\text { timing counting, } \\
\text { related instructions }\end{array}$ & $\begin{array}{l}\text { Timer structure, work and } \\
\text { application, memory } \\
\text { structure, access and } \\
\text { extension, delay program }\end{array}$ & $\begin{array}{l}\text { Realization of } \\
\text { external pulse } \\
\text { counting }\end{array}$ \\
\hline 4 & $\begin{array}{l}\text { Control output } \\
\text { signal }\end{array}$ & Instructions related I/O & $\begin{array}{l}\text { Interrupt programming, } \\
\text { related instruction }\end{array}$ & $\begin{array}{l}\text { Counting and } \\
\text { output a pulse }\end{array}$ \\
\hline 5 & $\begin{array}{l}\text { Case simulation } \\
\text { and production } \\
\text { display }\end{array}$ & $\begin{array}{l}\text { Development process } \\
\text { of SCM, hardware } \\
\text { schematic diagram and } \\
\text { program block diagram }\end{array}$ & $\begin{array}{c}\text { Drawing and programming } \\
\text { of hardware schematic } \\
\text { diagram }\end{array}$ & $\begin{array}{l}\text { Realization of } \\
\text { simple traffic light } \\
\text { control system }\end{array}$ \\
\hline 6 & $\begin{array}{l}\text { Case simulation } \\
\text { and } \\
\text { demonstration }\end{array}$ & $\begin{array}{l}\text { Simulation method, } \\
\text { PCB design }\end{array}$ & $\begin{array}{l}\text { Drawing of hardware } \\
\text { schematic, hardware } \\
\text { making, and debugging }\end{array}$ & $\begin{array}{c}\text { Implement } \\
\text { complete counting } \\
\text { output }\end{array}$ \\
\hline
\end{tabular}

On the basis of the completion of the case analysis table, complete the writing of related documents and typical demonstrations.

\subsection{Case Education Implementation}

Students gradually achieve the task goals in the case analysis table. The realization of the case should be based on students, and teachers play the role of supervision and guidance. Students are grouped rationally according to their ability to match. Each group consists of 4-5 people. In this way, it can not only avoid the situation of mutual plagiarism, but also cultivate the ability of the students to cooperate with each other. Teachers only need to arrange tasks, and explain the requirements of tasks and knowledge points involved, finally demonstrate typical examples of programs. The others are groped by the students themselves. If the students are confronted with problems that are difficult to solve, the teacher will provide the corresponding help.

After completion of each group, students discuss the case and demonstrate the implementation effect and innovation of the case at a specific time, and put forward the problems encountered in the production process. Teachers check the program of students' development, observe the effect and evaluate the results synthetically. After the course, we should discard the traditional way of written examination. Based on the completion of the tasks and cases, the students' completion situation is graded by means of defense and other means. Through summaries, we help students understand the knowledge points and guide students to expand cases, so as to transfer knowledge and skills. 
In case teaching, summary is also an essential part. On the one hand, we should reintegrate the acquired knowledge according to our way of thinking and build our own knowledge system; on the other hand, we should summarize the problems and accumulated experience in the process of completing to improve our abilities. We can improve the practice process of practice to theoretical level, understand and deepen through summarizing, and finally establish the knowledge system related to theoretical knowledge and practical application.

\section{Conclusion}

Cases based teaching overcome shortcomings of the traditional microcomputer principle and application teaching. It is easier to mobilize students' interest in learning, improve their abilities of analysis, hands-on, innovation, etc. Through the teaching reform of the curriculum, the effect of "less learning hours and same learning and training content" will be achieved. So that students can improve their practical ability effectively, cultivate their good sense of innovation and cooperation spirit, improve their comprehensive application ability and teaching effect.

\section{References}

[1]. Li Qing,Wang Tao.MOOC: A Connectedness Based Mega Open Course Model[J]. Distance Education In China,2012(3): 31

[2]. Zhang Hongwei,Wang Xinhuan, Wang Xin. Based on Proteus and Keil Microcontroller Practice Teaching Reform[J]. Journal of Electrical \& Electronic Engineering Education,2008,30 (6):6465.

[3]. Long Zhiqiang,Shi Xiaohong, Xie Yunde. The practice of "task driven method" in the teaching of MCU system design[J]. Research and Exploration in Laboratory, 2008, 27(3):101-102.

[4]. Ni Zhilian. The experimental teaching reform of the single chip computer course reform [J]. Research and Exploration in Laboratory,2006,25(7):843-844.

[5]. Tang Yonghong. Practical teaching of microcontroller[J]. Journal of Electrical \& Electronic Engineering Education,2007,29(1): 72-74. 